\title{
Land use and land cover analysis of Chiplun tehsil of Maharashtra using remote sensing and GIS
}

\author{
V. P. Mane, R. R. Gawali and A. P. Bowlekar
}

Received : $12.08 .2019 ;$ Revised : $30.08 .2019 ;$ Accepted : 19.09 .2019

See end of the Paper for authors' affiliation

Correspondence to :

\section{A. P. Bowlekar}

Dr. Budhajirao Mulik College of Agricultural Engineering and Technology, Mandki-Palvan, Ratnagiri (M.S.) India

Email: adwaitbowlekar1808 @ gmail.com
- ABSTRACT : The land use and land cover of Chiplun tehsil were determined by using the Landsat images of 20,30 and $40 \mathrm{~m}$ resolution, downloaded from GLCF-data imaginary via FTP server by selecting suitable path and row values on Google. The entire area of Chiplun tehsil was classified under the various land use and land cover classes such as water bodies, barren land, forest, settlement and agriculture land covering the area of 8.81, 250.98, 346.47, 26.06 and 487.32 $\mathrm{km}^{2}$, respectively. Total area for this classification was found to be $1119.64 \mathrm{~km}^{2}$ with Arc GIS 10.3 software with the per cent error of 0.02 per cent compared to actual area of Chiplun tehsil.

- KEY WORDS : Land use, Land cover, Area, Chiplun

- HOW TO CITE THIS PAPER : Mane, V.P., Gawali, R.R. and Bowlekar, A. P. (2019). Land use and land cover analysis of Chiplun tehsil of Maharashtra using remote sensing and GIS. Internat. J. Agric. Engg., 12(2) : 261-263, DOI: 10.15740/HAS/IJAE/12.2/261-263. Copyright@ 2019: Hind Agri-Horticultural Society. 